tionately and sometimes derisively as little Neddies, covering about two-thirds of private industry, with representatives from management and unions. When the results of their deliberations are known the Government will add them to results from its own studies and produce a more detailed planning document in the autumn. It is acknowledged that prices and incomes will be important considerations in any plan of this kind. The whole subject of national planning has been regarded rather sceptically since the National Plan was abandoned in July 1966, but it is thought that the present state of the economy calls for another attempt, provided that it is more flexible than the last.

\section{New Look for Heathrow}

THe British Airports Authority, which runs commercial airfields in Britain, last week unveiled plans for the development of Heathrow, London's major airport. With the advent of the Bocing 747 , which will be arriving on commercial flights to London by the summer of 1970 , development of Heathrow to handle the increase in passengers has become urgent. Although the new plan is to cost $£ 10$ million, it represents a face-lift for only a small part of the airport.

The new section of the airport will be a T-shaped pier, with an upright $900 \mathrm{ft}$. long and a crosspiece $1,000 \mathrm{ft}$. long. The aircraft stands will be positioned along the crosspiece, seven each side, and passengers will be carried along the upright section on a travelling pavement. For those who prefer to make the journey on foot, ample space will be provided on either side of the conveyor. Telescopic air jetties will link the aircraft with waiting rooms. There will also be changes in the terminal buildings; a new passenger terminal building, prosaically called Terminal 1 , will be built, and the existing Europa and Britannic buildings will be merged and called Terminal 2 . The Oceanic building will be renamed Terminal 3 , and a new arrivals terminal will also be built. By the time the 747 service across the Atlantic is in full swing, it will be necessary to separate arriving and departing passengers into two separate terminals. Thus by 1970 , Terminal 3 (the Oceanic building to today's travellers) will be devoted to departing passengers, while the new arrival terminal looks after those coming into Britain. By this time, the authority says, the number of departing and arriving passengers on long haul services is likely to reach 2,700 an hour in each direction.

The main difficulty will arise when several $747 \mathrm{~s}$ arrive at once, or within a few minutes of each other. Each will be carrying up to 490 passengers. Unless the capacity of the airport bus services is to be severely overstretched, a rail link between central London and the airport must be built.

\section{Marine Science on Record}

The first comprehensive directory of marine seience in the United Kingdom has just been published (The Royal Society, £2). It has been prepared on behalf of the Royal Society's British National Committee for Oceanographic Research with the co-operation of the Natural Environment Research Council, and it should prove to be of great help to everyone working in this rapidly growing subject.

For the most part, the book consists of the names of scientists listed by establishment and arranged in four sections. Sections 1 and 2 include the marine science laboratories, both government and university, with details of the scientists employed in them and of the laboratories themselves. Information given under each institution includes facilities for visiting research workers, training courses, and a selected bibliography of research done there. There are as many as 57 university departments in the United Kingdom which have continuing interests in marine science.

Sections 3 and 4 cover university departments and government-supported laboratories in which marine seience has only a minor role-but where there are staff working on some aspect of the subject. A further 42 academic and 13 government-supported departments are listed in these sections.

There is often confusion over the organization of research in interdisciplinary fields such as oceanography. It is helpful, therefore, that the directory includes a summary of the overall organization of oceanographic and fisheries research in the United Kingdom and the part played by the national programme in international activities.

The research ships available to British scientists and the libraries offering facilities to them are listed in two appendices.

\section{Scientist on the Move}

Mr B. T. Price, at present director of the Defence Operational Analysis Establishment of the Ministry of Defence at Byfleet in Surrey, is to become Chief Scientific Adviser at the Ministry of Transport on April 1. Mr Price has worked in turn for the Atomic Energy Authority and for the scientific group at the headquarters of the Ministry of Defence. He has been largaly responsible for setting up the Byfleet establishment in the past few years. He is a physicist by trade.

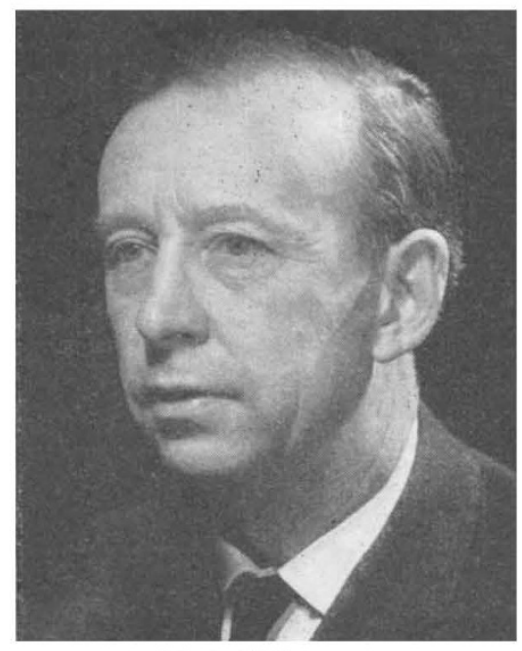

Mr B. T. Price.

This new appointment comes at a time when it seems that the Ministry of Transport would like to see more of what the British Government spends on research and development devoted to the art of moving about.

\section{Make or Break}

DURINa the past year or so, the Electrical Research Association has done its share of breast-beating in 
public. The decision by the Central Electricity Generating Board to withdraw its habitually automatic support was a shock from which ERA has taken some time to recover. Now, although workers at ERA are hoping the worst is over, there is still a certain amount of belt tightening to be done.

Under a scheme to be introduced next year, each item of research carried out at ERA will have to be individually sponsored. This is a system which will doubtless help to raise sums of money for jobs for individual companies, but is unlikely immediately to help ERA to continue work which is of general interest to the entire industry. The more general a problem, the less likely a company is to feel responsible for it. This difficulty is going to hit hardest at the work which is of greatest public concern-the safety of electrical devices, as ensured by the correct design of fuses. FRA performs a continuing service for fuse manufacturers, not least by ensuring that British companies keep up with changes in international standards, now recognized as a major barrier to successful exporting. The same section at ERA which is responsible for fuses also works on contractors, and has recently been able to show that British manufacturers were producing a product which was uneconomic because the standards were too stringent.

ERA has now published a summary of the literature in fuses between 1950 and 1965 (Advances in Electrical Fuses, by H. W. and C. Turner, ERA, 54s.). This, it is hoped, will stimulate British manufacturers to increase support for this important part of ERA's activities.

\section{Biology of Barrages}

Work is now in progress on the biological effects of the proposed barrage across Morecambe Bay. The full feasibility study announced early last year by the Water Resources Board is to cost about $£ 500,000$ and is expected to last another 2 to 3 years. By then the board, with reports in hand representing all sides of the project, should be able to advise the government whether the barrage is a workable proposition.

An important aspect of any barrage scheme is the effect the works will have on the ecology and fisheries of the area. The biologists must try to predict what will happen to the different animals and plants, bearing in mind the usefulness of the impounded water, the amenities of the area, the fisheries, and so on. One of the biological techniques used for a study of this kind is to find the nearest parallel project. Unfortunately, there are few examples of similar estuarine barrages to which the biologists can turn. The conversion of the Zuider Zee into the Ijsselmeer in Holland, however, may have some relevance, and Loch Neagh in Northern Ireland shows some similarities although it is an inland lake. Two biologists who are to work on the Morecambe Bay barrage have now been appointed by the Natural Environment Research Council. The co-ordinator of the ecological work is $\mathrm{Mr}$ John Corlett, who has been seconded to the Windermere Laboratory of the Freshwater Biological Association from the Fisheries Laboratory, Lowestoft. His assistant is based at the University of Lancaster.

The Nature Conservancy is also assisting in the study in several ways. A small department to study the overall conservation of large scale proposals has been recently established at the Nature Conservancy station at Shrewsbury under the direction of Dr R. J. Elliott. The proposed barrage is one of the projects with which it will be concerned, and it will keep in touch with the regional conservation staff and other interested parties. Meanwhile, a small ornithological project on waders is in operation in co-operation with the Royal Society for the Protection of Birds and the Ministry of Agriculture. It is necessary to know how many of these birds there are in the estuary and what they feed on. The Nature Conservancy has therefore issued a licence for a few waders to be shot so that their stomach contents can be analysed. Work on the coastal ecology of the estuary will be done from the Nature Conservancy's station at Merlewood, Grangeover-Sands.

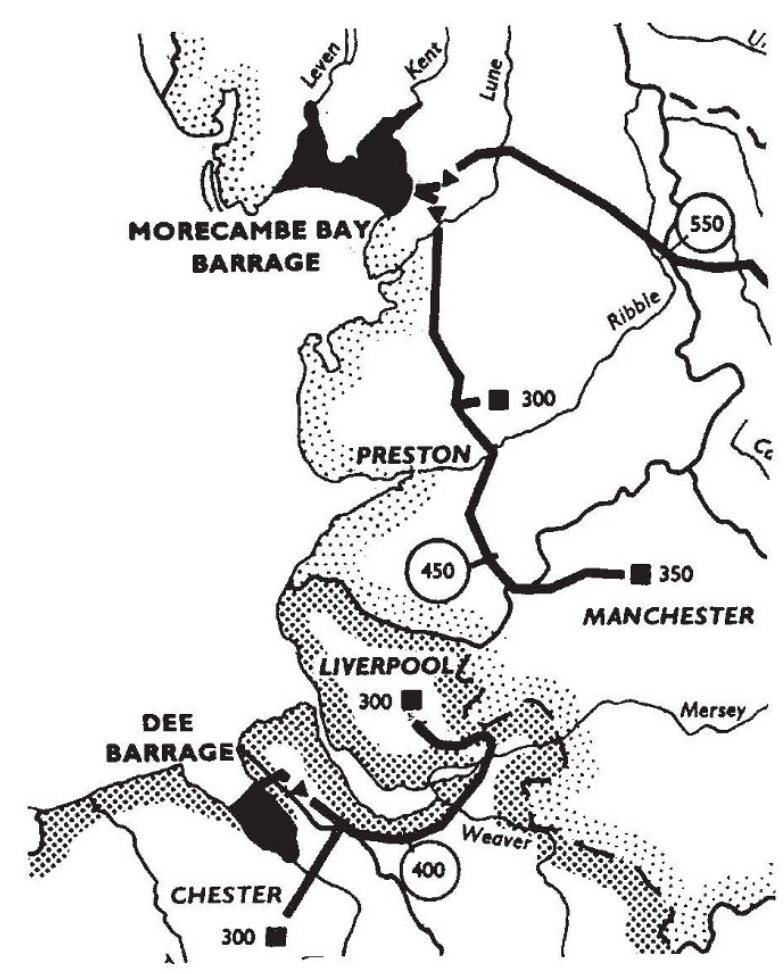

The Morecambe Bay and Dee Barrages, with a suggested distribution system.

It will be some time before all the data collected can be assembled into a meaningful whole, but there is no doubt that there will be some important biological factors for the engineers to bear in mind when or if they come to actually designing the barrage.

\section{Astronomers at Brighton}

For the first time since 1925, the General Assembly of the International Astronomical Union is to be held in Britain. The next Assembly-the fourteenth-will meet in 1970 at the University of Sussex, near Brighton, from August 18 to 27. Judging by the numbers at previous Assemblies-the thirteenth was held in Prague last year-about 2,000 astronomers are expected to attend.

The chairman of the Preparatory Organizing Committee, Dr D. H. Sadler of the Royal Greenwich Observatory, is hoping that observatories and astronomy institutes in Britain will arrange visits for the 